\begin{tabular}{l} 
JOURNAL OF EMPOWERMENT \\
VOL. 2, No. 1, Juni 2021., h. 76-88 \\
ISSN 2580-0620 (Print) \\
ISSN 2597-9809 (Online) \\
Available Online at https://jurnal.unsur.ac.id/index.php/JE \\
\hline \hline
\end{tabular}

\title{
PELAKSANAAN PEMBERIAN BANTUAN SOSIAL KEPADA KORBAN BENCANA BANJIR DAN LONGSOR
}

\section{IMPLEMENTATION OF PROVISION OF SOCIAL ASSISTANCE TO VICTIMS OF FLOOD AND LANDSLIDE DISASTER}

\author{
Sya'baningrum Prihhartini', Reza Anggriyashati Adara'2, Siti Khadijah ${ }^{3}$ \\ FKSB Universitas Islam 45 Bekasi \\ syabaningrum@englitbekasi.org \\ FKSB Universitas Islam 45 Bekasi \\ reza.adara@gmail.com \\ FKSB Universitas Islam 45 Bekasi \\ kh4di1ja4h@gmail.com
}

\begin{tabular}{|l|l|l}
\hline Masuk : 18 Februari 2021 & Penerimaan : 04 Mei 2021 & Publikasi : 01 Juni 2021
\end{tabular}

\begin{abstract}
ABSTRAK
Bencana banjir dan longsor secara beruntun menimpa Desa Cileuksa, Kecamatan Sukajaya, Kabupaten Bogor, Jawa Barat pada tanggal 1 Januari 2020. Ribuan orang harus dievakuasi karena rumah-rumah mereka disapu banjir dari Sungai Cidurian. Walaupun terjadi setahun yang lalu, para penyintas masih terpaksa tinggal di tempat pengungsian yang dibangun oleh tentara. Selain bencana tersebut, bencana lain terjadi di Kabupaten Bekasi pada tanggal 7 Februari 2021 dan menghancurkan banvak rumah. Bencana ini teriadi di tengah pandemi Covid-19 yang telah berdampak buruk terhadap kondisi ekonomi dan kesehatan masyarakat. Demi meringankan beban para korban, FKSB Universitas Islam 45 Bekasi berinisiasi membuat sebuah program pengabdian masyarakat yang terdiri dari kampanye penggalangan dana, menggalang dana dari masyarakat dan kerjasama dengan Kwartir Cabang Pramuka Kabupaten Bekasi. Program ini diharapkan bisa meningkatkan kesadaran tentang pentingnya penyediaan bantuan terhadap korban-korban bencana. Data dari hasil survei kepada para penerima bantuan menunjukkan bahwa masyarakat penerima bantuan merasa puas dengan bantuan yang diberikan. Program pengabdian masyarakat ini diharapkan bisa menjadi titik tolak bagi dari program-program pengabdian masyarakat selanjutnya yang akan ditekankan kepada pemberdayaan masyarakat di daerah bencana.
\end{abstract}

Kata Kunci : Longsor; Sosial; Pengabdian.

\begin{abstract}
On January 1st, 2020, a flood which was succeeded with landslides struck Desa Cileuksa, Kecamatan Sukajaya, Kabupaten Bogor, Jawa Barat. Thousands of people were evacuated because their homes were swept by floods from Sungai Cidurian. Although the disaster happened a year ago, the survivors still suffer from the aftermath as they still have to live in shelters built by army. Besides that, another flood disaster took place in Kabupaten Bekasi on February 7th, 2021 in Kabupaten Bekasi and destroyed many houses. These disasters took places amid Covid-19 pandemic which has negatively affected people's economic and health conditions. In order to provide reliefs to survivors, FKSB Universitas Islam 45 Bekasi initiated a social service program. The program consists of creating a campaign for charity program, raising donations from public, and working together with Kwartir Cabang Pramuka Kabupaten Bekasi. The program aims to raise awareness for provision of reliefs toward disasters' survivors. The survey results show that most recipients are satisfied with the relief's provision. The present program is expected to be a milestone for further programs which aim to the empowerment of disasters' survivors.
\end{abstract}

Keywords : Landslides; Charity; Social. 


\section{A. PENDAHULUAN}

Salah satu peristiwa yang berdampak buruk terhadap kelangsungan hidup manusia adalah bencana alam. Dalam hal ini, bencana didefinisikan oleh Undang-Undang No. 24 Tahun 2007 sebagai peristiwa atau rangkaian peristiwa yang mengancam dan mengganggu kehidupan masyarakat yang disebabkan oleh faktor alam atau nonalam dan mengakibatkan timbulnya korban jiwa manusia, kerusakan lingkungan, kerugian harta benda dan dampak psikologis. Lebih lanjut lagi bencana dibagi menjadi bencana alam dan non-alam. Apabila bencana alam disebabkan oleh faktor-faktor natural seperti gempa bumi, tsunami, gunung meletus, dan banjir, bencana non-alam bisa disebabkan oleh faktor-faktor seperti konflik sosial, teror dan sebagainya. Bencana alam bisa berdampak negatif terhadap masyarakat seperti kegelisahan, tekanan batin dan gangguan kepribadian (Faradilla, 2018; Nur \& Dampung, 2020). Berdasarkan poin-poin diatas, bencana dapat berdampak negatif terhadap seseorang.

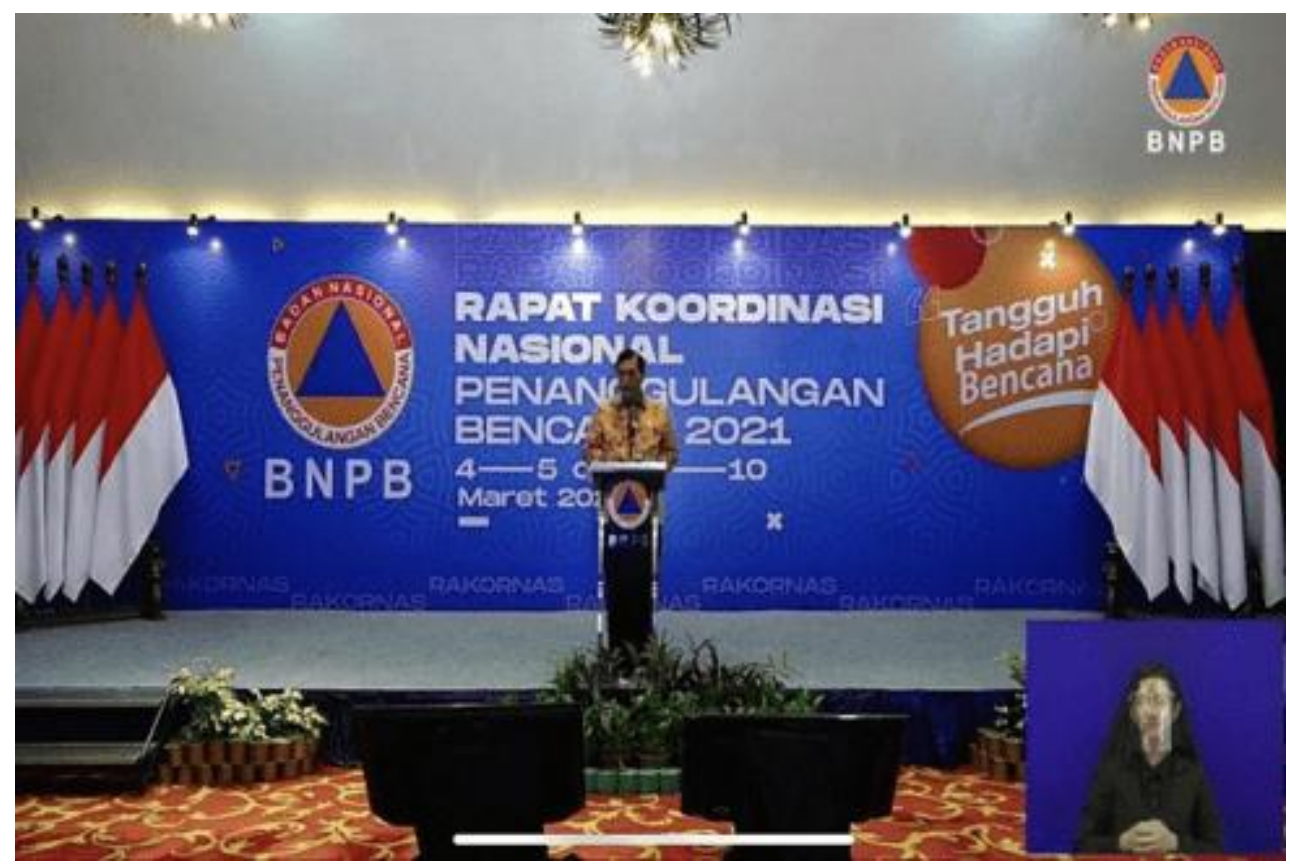

Gambar 1. Rapat Koordinasi Penanggulangan Bencana 2021 Sumber: Sindonews.com

Berkenaan dengan bencana, Indonesia telah dinyatakan sebagai salah satu negara yang rawan bencana menurut United Nations International Strategy for Disaster Reduction (UNISDR) dan menduduki urutan ke-6 di antara negara-negara (BAPPENAS, 2006; UNISDR, 2009). Pernyataan diatas menunjukkan bahwa Indonesia masih merupakan negara yang rawan bencana (Putra \& Faisal, 2018). Dalam sebuah acara berkenaan dengan rapat koordinat penanggulangan bencana, Menteri Koordinator Bidang Kemaritiman, Luhut Binsar Panjaitan mengatakan bahwa Indonesia merupakan negara yang termasuk ke dalam 35 negara yang rawan bencana. Potensi tersebut harus disiasati dengan baik melalui kesiapan terhadap bencana, baik alam maupun non-alam (Binti Mufarida, 2021).

Selain itu, Doni Monardo selaku Kepala Badan Nasional Penanggulangan Bencana (BNPB) menyatakan Indonesia merupakan negara yang rawan bencana karena di tahun 2015 terjadi 1.694 bencana yang mengakibatkan 276 jiwa meninggal atau hilang dan 1,2 juta orang mengungsi. Di tahun 2016, terjadi 2.384 bencana yang 
mengakibatkan 521 jiwa meninggal atau hilang dan 3,2 juta warga mengungsi. Jumlah tersebut naik di tahun 2019 dan 2020 (CNN, 2020).

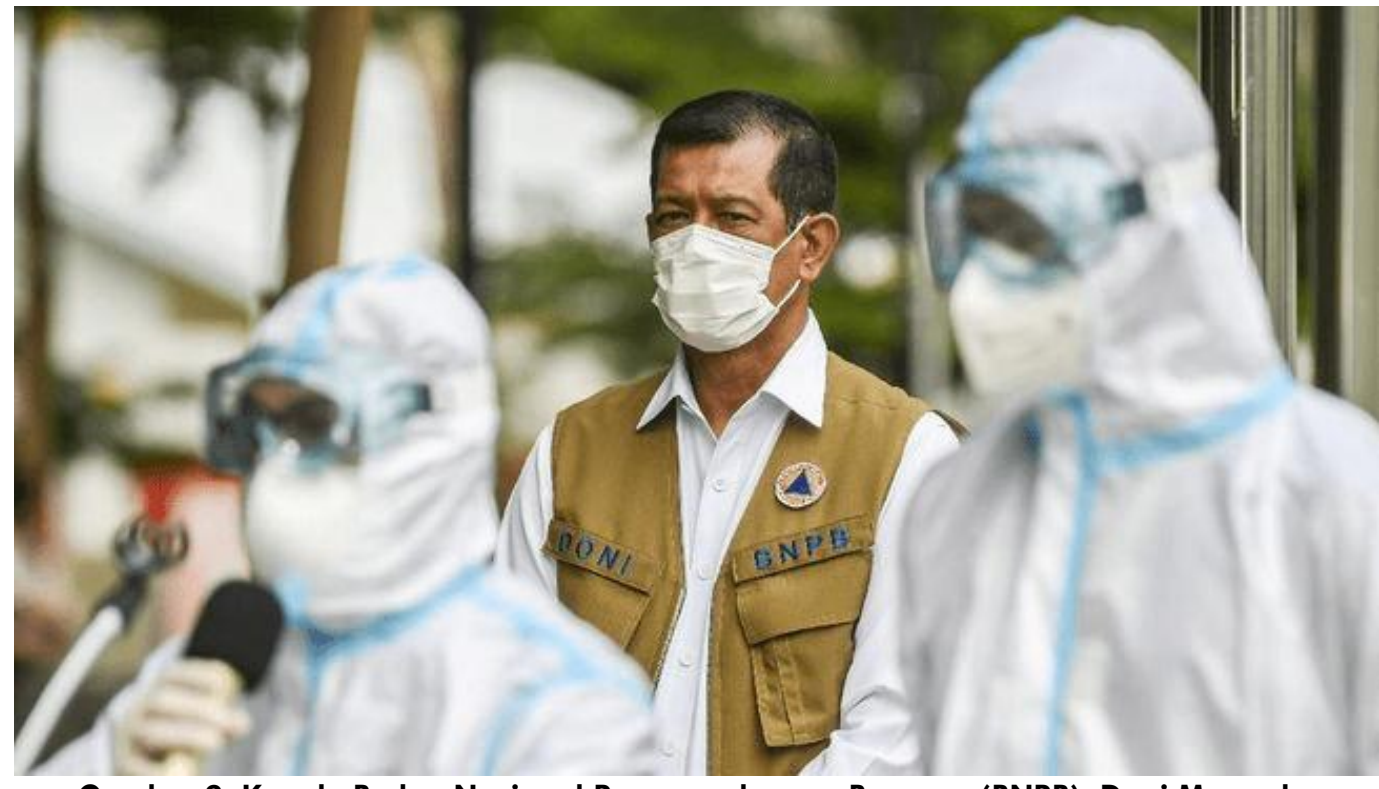

Gambar 2. Kepala Badan Nasional Penanggulangan Bencana (BNPB), Doni Monardo.

Banjir, sebagai salah satu jenis bencana alam, merupakan bencana yang paling sering terjadi di Indonesia (Yunida et al, 2017). Dalam hal ini, banjir dianggap sebagai bencana alam yang perlu mendapat perhatian karena merupakan bencana alam ketiga terbesar di dunia dan banyak menelan korban jiwa dan kerugian baik materiil maupun immateril (Umar Nurlailah, 2013). Indonesia juga dianggap sebagai negara yang berpotensi tinggi terdampak banjir dan longsor. Selain faktor-faktor seperti curah hujan yang tinggi, perubahan iklim global, perubahan penggunaan lahan, bertambahnya jumlah penduduk, urbanisasi, kemiskinan menjadi penyebab peningkatan bencana banjir dan longsor. Daerah-daerah yang berpotensi rawan banjir adalah sepanjang pantai timur Sumatera, Pantura, Kalimantan, dan daerahdaerah sepanjang sungai. Selain itu daerah- daerah pegunungan dan perbukitan yang banyak penduduknya juga patut diperhatikan sebagai daerah rawan banjir (Besty Charmin Simatupang, 2018; Khadafi, 2021). Selain itu, Kementerian Pekerjaan Umum dan Perumahan (PUPR) mengatakan bahwa penanganan banjir di Indonesia belum efektif karena daerah-daerah yang terdampak banjir di Indonesia makin meningkat. Bahkan di awal tahun 2021, Kalimantan Selatan mengalami banjir terbesar selama 50 tahun terakhir. Hal tersebut disebabkan oleh kerusakan daerah sungai (Emir Yanwardhana, 2021). Beberapa faktor lain juga menjadi penyebab mengapa banjir sering terhadi di Indonesia. Penelitian Rizkiah et al (2015) terhadap penyebab-penyebab banjir di salah satu daerah di Indonesia menyebutkan curah hujan yang tinggi, perubahan tata guna lahan dan kawasan resapan air yang berkurang dan sedimentasi sungai. Banjir juga memberikan dampak buruk terhadap masyarakat. Banjir juga menyebabkan kerugian material dan immaterial terhadap masyarakat. Penelitian Yunida et al (2017) terhadap efek-efek bencana banjir terhadap kondisi sosial ekonomi masyarakat menyebutkan penurunan kesehatan, penurunan penghasilan, hambatan dalam kegiatan sehari-hari sebagai efek-efek paling parah dari bencana banjir. Penelitian (Hapsoro \& Buchori, 2015) juga menyatakan bahwa sebuah daerah bisa menjadi rentan apabila daerah tersebut terkena banjir. Oleh karena intensitasnya yang sering dan efek-efek negatif banjir 
terhadap masyarakat, para korban banjir patut mendapatkan perhatian lebih dari berbagai kalangan.

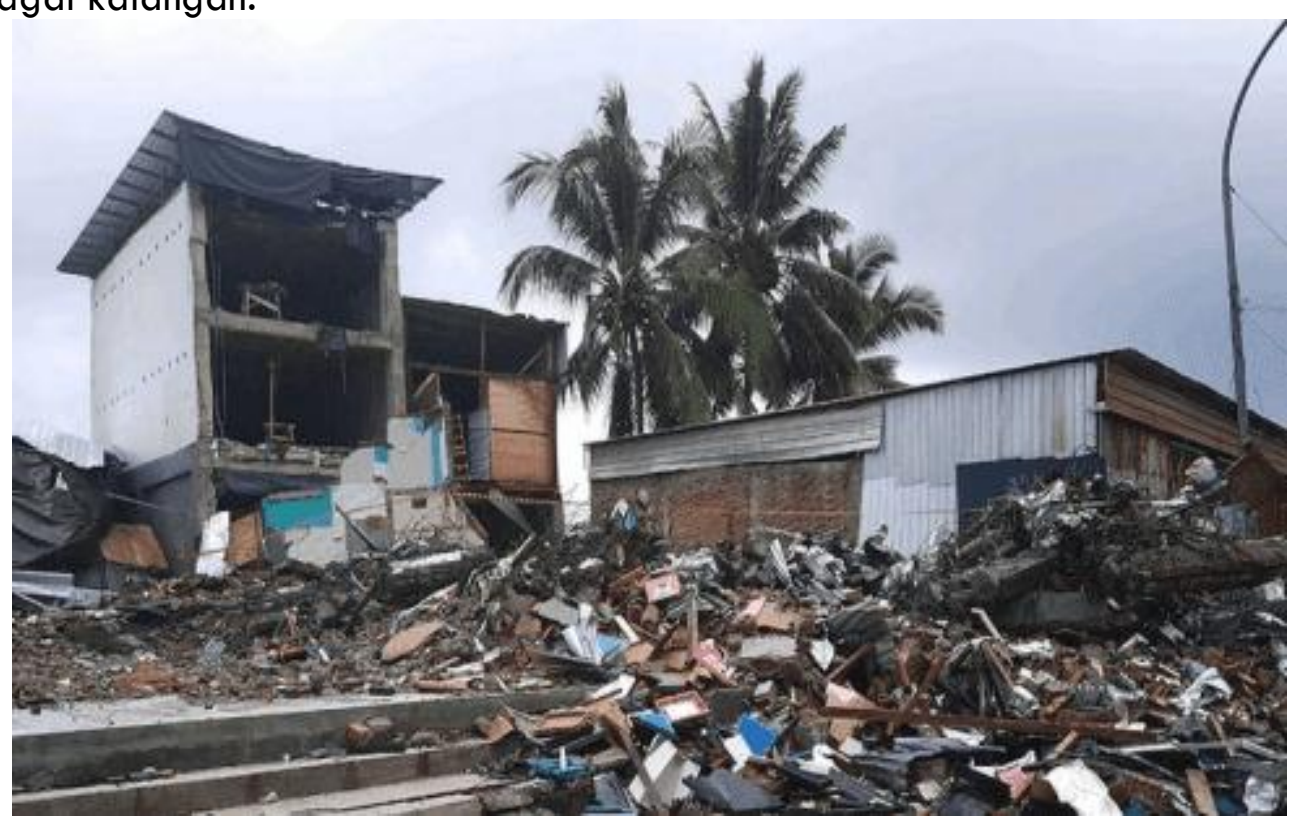

Gambar 3. Akibat bencana banjir

Sumber: BPBD Kabupaten Majene

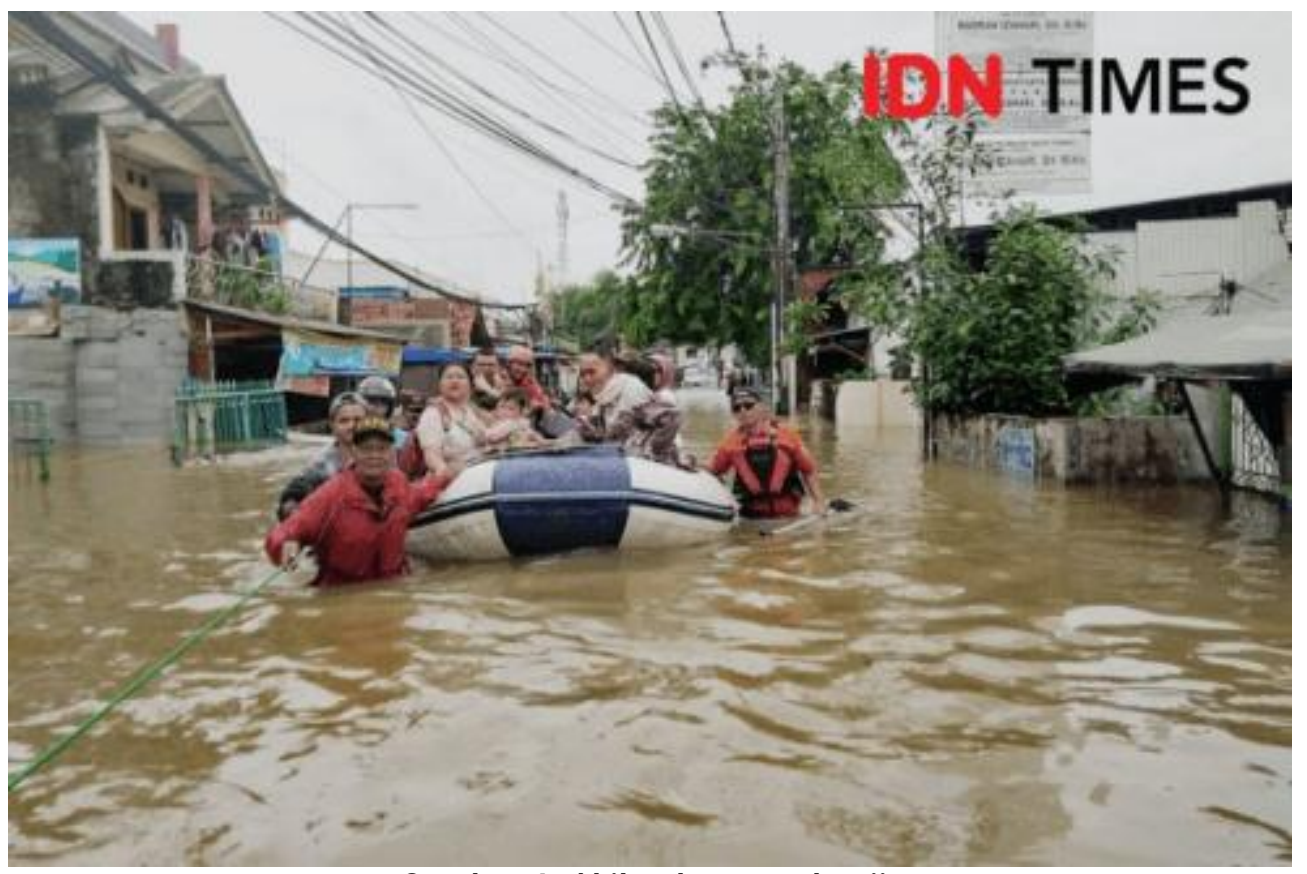

Gambar 4. Akibat bencana banjir Sumber: IDN Times

Beberapa program sudah dilakukan untuk meminimalisir penderitaan para penyintas bencana banjir seperti penyaluran bantuan makanan kepada keluarga terdampak banjir di Kalimantan Selatan (Yuni Astutik, 2021) dan bantuan rumah untuk korban terdampak bencana (Friski Riana, 2021). Walaupun begitu, masih banyak daerah terdampak bencana banjir yang Masih membutuhkan bantuan dari berbagai pihak.

FKSB Universitas Islam 45 Bekasi memiliki visi sebagai fakultas yang bertujuan menghasilkan insan khairu ummah yang berkebangsaan, berorientasi ilmu 
pengetahuan, teknologi dan berwawasan technopreneur. Selain itu FKSB Universitas Islam 45 Bekasi memiliki misi untuk menanamkan nilai-nilai Islami dan kebangsaan yang berpedoman pada Al-Qu'ran dan As-Sunnah. Sebagai bagian dari usaha untuk menuangkan visi dan misi tersebut ke dalam tindakan, FKSB Universitas Islam 45 Bekasi membuat kegiatan Pengabdian Pada Masyarakat (PPM) yang berbentuk bakti sosial. Hal tersebut sejalan dengan ayat Al-Qu'ran berikut ini

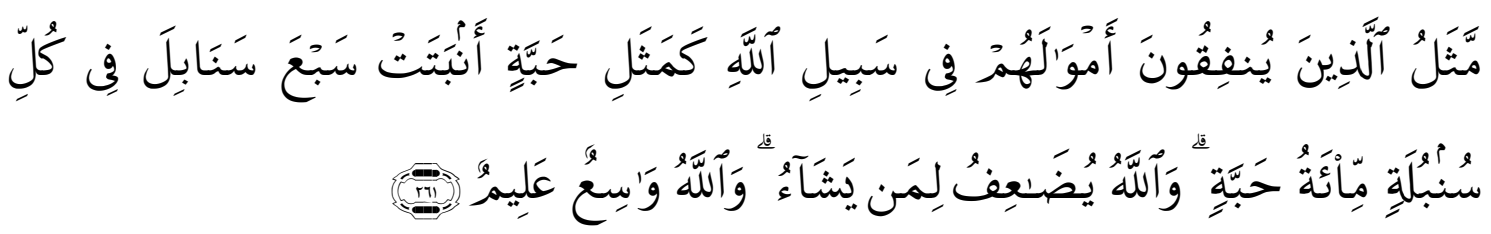

261. perumpamaan (nafkah yang dikeluarkan oleh) orang-orang yang menafkahkan hartanya di jalan Allah[166] adalah serupa dengan sebutir benih yang menumbuhkan tujuh bulir, pada tiap-tiap bulir seratus biji. Allah melipat gandakan (ganjaran) bagi siapa yang Dia kehendaki. dan Allah Maha Luas (karunia-Nya) lagi Maha mengetahui.

[166] Pengertian menafkahkan harta di jalan Allah meliputi belanja untuk kepentingan jihad, pembangunan perguruan, rumah sakit, usaha penyelidikan ilmiah dan lain-lain.

Selain itu, kegiatan pengabdian masyarakat ini dilakukan sebagai bagian dari tridharma perguruan tinggi yaitu; pengajaran, penelitian dan pengabdian masyarakat. Ketiga elemen ini merupakan bentuk keterlibatan perguruan tinggi terhadap pembangunan dan menghilangkan isolasi dunia akademik terhadap persoalan masyarakat. Di lain pihak, masyarakat juga akan memberikan pelajaran berharga kepada perguruan tinggi terhadap realitas kehidupan (Wulandari, 2016). Kegiatan pengabdian masyarakat ini juga merupakan bagian dari peningkatan softskills bagi sivitas akademik. Dałam era pandemi seperti sekarang, langkah jangka pendek seperti pembagian sembako dapat membantu masyarakat (UNS, 2020). Pendapat-pendapat di atas menunjukkan pentingnya pengabdian masyarakat, baik dari sisi agama maupun sisi perguruan tinggi.

Dengan mengadakan kegiatan bakti sosial, seluruh sivitas FKSB Universitas Islam 45 Bekasi diharapkan bisa memberikan contoh nyata kepada civitas akademik dan publik mengenai pentingnya menjadi insan yang berguna bagi lingkungan sekitar. Berkenaan dengan itu, dalam kegiatan Pengabdian Kepada Masyarakat di tahun 2021 ini, FKSB Universitas Islam 45 Bekasi mengadakan kegiatan bakti sosial di Desa Cileuksa, Kecamatan Sukajaya, Kabupaten Bogor, Jawa Barat. Kegiatan ini dilakukan karena para penyintas bencana banjir dan longsor yang menimpa Desa Cileuksa masih memerlukan bantuan dari berbagai pihak. Berikut adalah poin-poin yang membuat Desa Cileuksa menjadi sasaran bakti sosial dari FKSB Universitas Islam 45 Bekasi.

Bencana banjir dan longsor di Desa Cileuksa teriadi pada tanggal 1 Januari 2020. Bencana tersebut disebabkan hujan deras yang turun sejak malam sebelumnya. Bencana banjir dan longsor ini mengambil enam korban jiwa dan menghancurkan 1.261 unit bangunan. Setahun setelah bencana terjadi, beberapa penyintas bencana banjir dan longsor Desa Cileuksa masih belum bisa kembali ke rumah mereka karena kampung mereka yang dianggap sebagai zona merah longsor (Reza Mardhani, 2020). 
Desa Cileuksa dilaporkan menjadi daerah terdampak banjir yang paling parah karena menjadi bagian dari zona merah yang berarti tidak dapat ditempati lagi. Selain itu, warganya masih menetap di tenda-tenda pengungsian yang sangat jauh dari kata layak (Indonesia Dermawan, 2020).

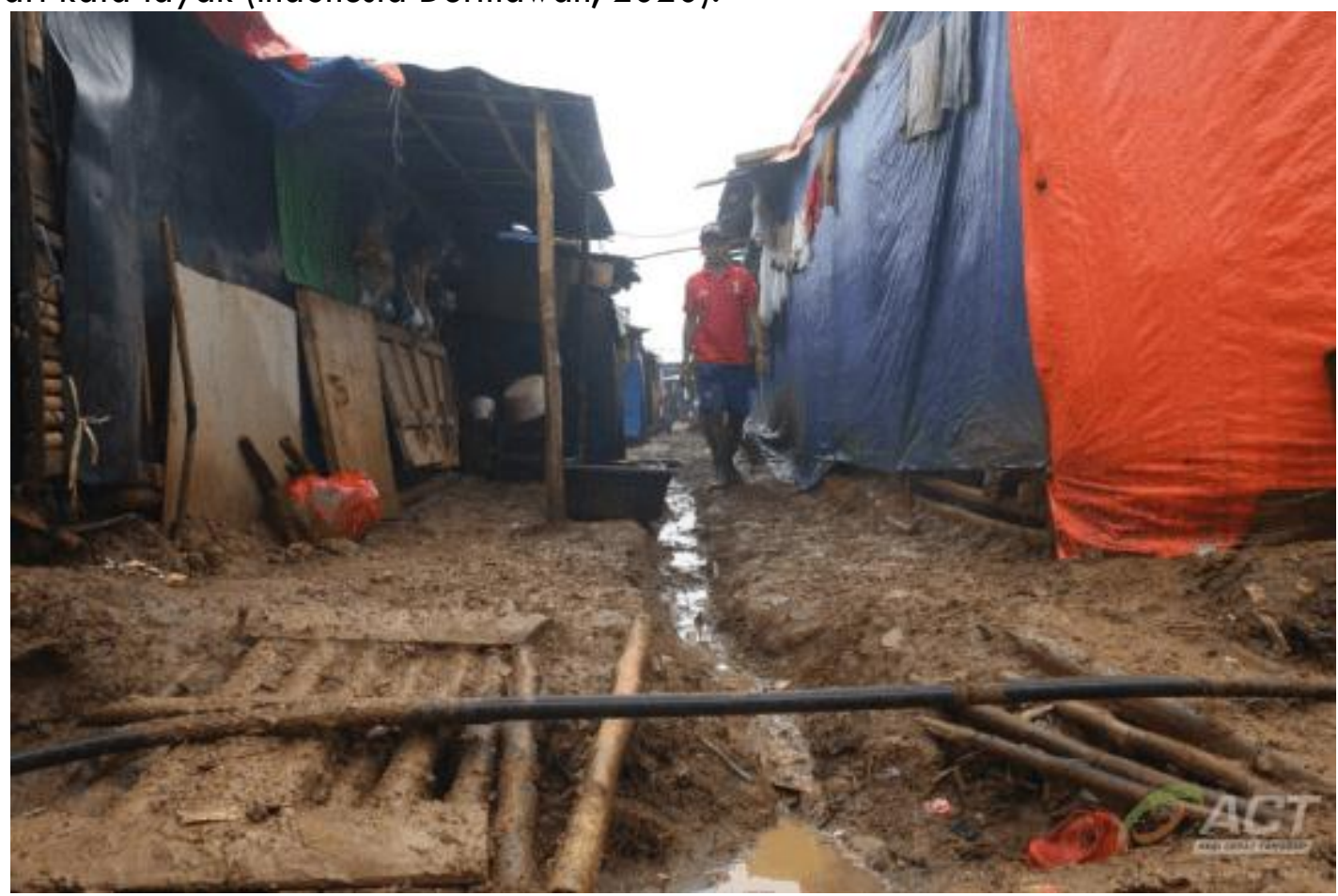

Gambar 5. Keadaan Tenda Pengungsian Desa Cileuksa Sumber: Indonesia Dermawan

Selain keadaan pengungsian yang kurang baik, para penyintas bencana banjir dan longsor masih harus dihadapkan dengan pandemi Covid-19. Berdasarkan Peraturan Pemerintah Republik Indonesia Nomor 21 tahun 2020 Tentang Pembatasan Sosial Berskala Besar yaitu Percepatan Penanganan Corona Virus Disease 2019 (Covid-19) dan Pemerintah Gubenur No. 443/kep-221-Hukham/2020 tentang Pemberlakuan PSBB di Bodebek (Bogor, Depok dan Bekasi), warga dihimbau untuk tidak keluar rumah untuk mencegah penyebaran Covid-19. Selain itu, Peraturan Daerah mengenai Pembatasan Sosial Berskala Besar yaitu Peraturan Bupati No. 16 Tahun 2020 menghimbau warga untuk membatasi keluar rumah. Keadaan tersebut bisa berdampak buruk bagi para penyintas bencana banjir dan longsor Desa Cileuksa. Mempertimbangkan keadaan-keadaan di atas, FKSB Universitas Islam 45 Bekasi memusatkan kegiatan bakti sosial kepada para penyintas bencana banjir dan longsor Desa Cileuksa untuk mengurangi beban yang dihadapi oleh para penyintas.

Selain bencana yang terjadi di Desa Cileuksa, bencana banjir juga menimpa Kabupaten Bekasi pada tanggal 7 Februari 2021. Bencana tersebut menghancurkan puluhan rumah dan membuat kehidupan masyarakat menjadi lebih buruk. Dilaporkan oleh Badan Penanggulangan Bencana Daerah (BPBD) Kabupaten Bekasi, hujan deras disertai angin kencang menyebabkan 12 Kecamatan terendam banjir dengan ketinggian sekitar 30 sampan 150 centimeter (Abdullah M Surjaya, 2021). 


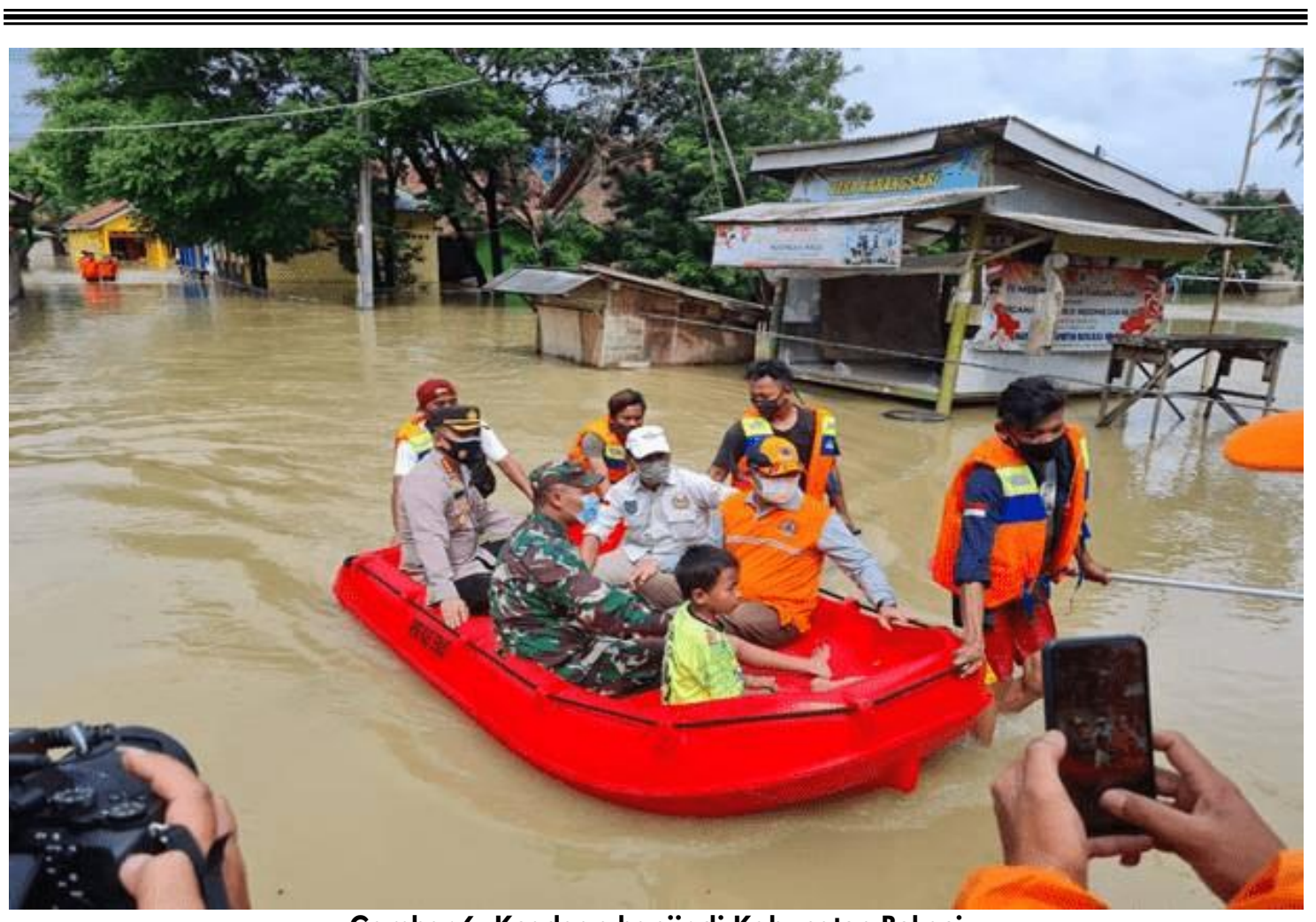

Gambar 6. Keadaan banjir di Kabupaten Bekasi Sumber: BPBD Kabupaten Bekasi

Berdasarkan keadaan lapangan, FKSB Universitas Islam 45 Bekasi pun mengadakan penyerahan kegiatan bantuan sosial kepada penyintas bencana banjir dan longsor di Desa Cileuksa dan Kabupaten Bekasi. Kegiatan ini merupakan bagian dari pengabdian masyarakat perguruan tinggi. Sebagai bagian dari tridharma perguruan tinggi, FKSB Universitas Islam 45 Bekasi diharuskan untuk membuat kegiatan pengajaran, penelitian dan pengabdian masyarakat. Hal tersebut merupakan bukti dari andil FKSB Universitas Islam 45 Bekasi terhadap kemajuan masyarakat. Selain mendidik mahasiswa dan membuat penelitian, FKSB Universitas Islam 45 Bekasi juga turut mengabdi kepada masyarakat yang telah memberikan dukungan kepada FKSB Universitas Islam 45 Bekasi.

\section{B. METODE}

Tujuan-tujuan pelaksanaan kegiatan PPM ini adalah menunjukkan tindakan nyata dari keperdulian sosial seluruh sivitas FKSB Universitas Islam 45 Bekasi. Metode kegiatan yang digunakan adalah mengumpulkan bantuan sosial berupa bahan pangan dan sandang dan bekerjasama dengan Kwartir Cabang Pramuka Kabupaten Bekasi sebagai pihak yang mendistribusikan bantuan kepada para penyintas bencana banjir dan longsor Desa Cileuksa.

Berikut adalah tahapan-tahapan yang dilakukan dalam penyaluran bantuan:

\section{Pembuatan Kampanye Penggalangan Dana}

Sebelum penyerahan bantuan, sebuah kampanye penggalangan dana dilakukan. Kampanye ini dilakukan secara daring dan melibatkan seluruh sivitas FKSB Universitas Islam 45 Bekasi. Penggalangan dana ini dilakukan selama 1 bulan. Berikut adalah poster penggalangan dana yang disebarkan ke publik: 


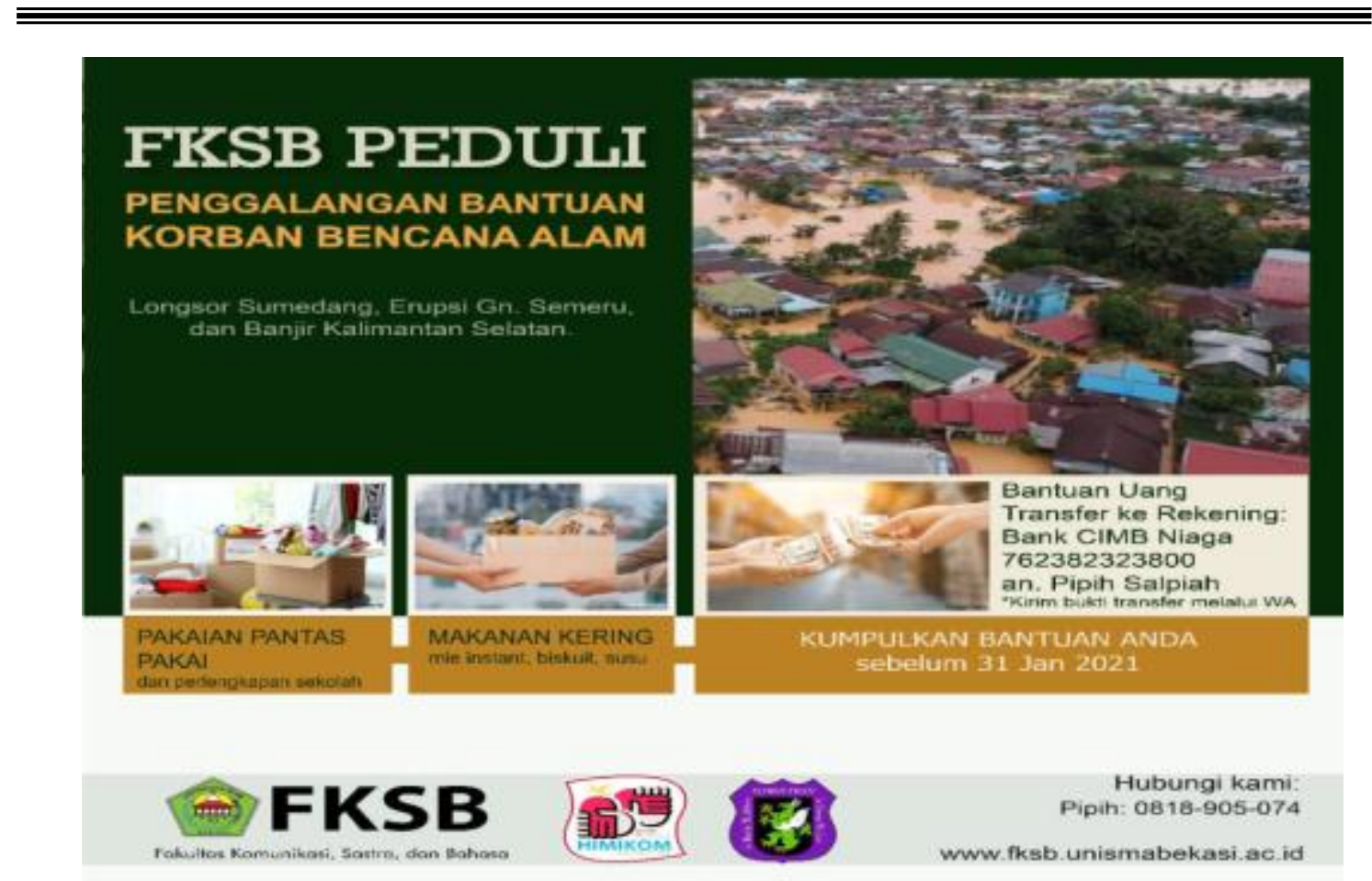

\section{Gambar 7. Poster Penggalangan Dana}

\section{Tahap Pengumpulan dan Penyortiran Bantuan}

Bantuan-bantuan yang sudah dikumpulkan kemudian disortir ke dalam beberapa kategori yaitu sandang dan pangan. Penyortiran tersebut dilakukan untuk mempermudah distribusi kepada para penyintas bencana banjir dan longsor Desa Cileuksa. Tahap ini dilakukan selama dua hari. Berikut adalah foto-foto penyortiran bantuan:
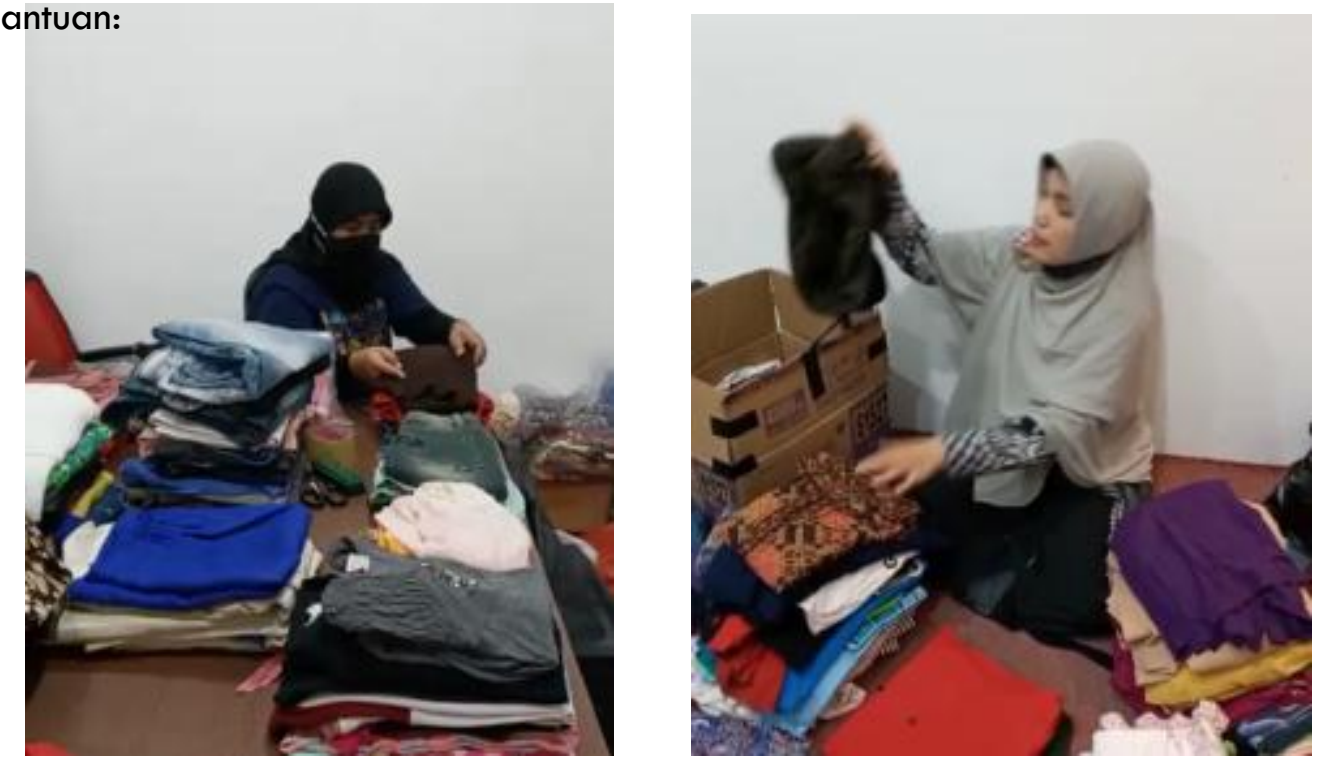


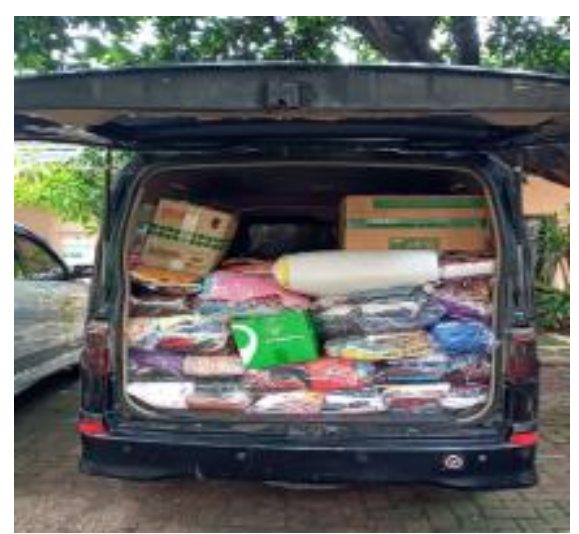

Gambar 8. Tahap Pengumpulan dan Penyortiran Bantuan

\section{Tahap Penyerahan Bantuan}

Setelah semua bantuan disortir dan dikemas rapih, bantuan kemudian diserahkan kepada Kwartir Cabang Pramuka Bekasi. Penyerahan dilakukan karena keadaan pandemi Covid-19 tidak memungkinkan bagi sivitas FKSB Universitas Islam 45 Bekasi untuk menyerahkan sendiri bantuan kepada para penyintas bencana banjir dan longsor Desa Cileuksa. Amanah tersebut juga dipercayakan kepada Kwartir Cabang Pramuka Kabupaten Bekasi karena dianggap telah berpengalaman untuk memberikan bantuan ke daerah-daerah bencana. Sedangkan bantuan yang diberikan ke Kabupaten Bekasi dilakukan sendiri oleh tim dari FKSB Universitas Islam 45 Bekasi. Berikut adalah tahap penyerahan bantuan:

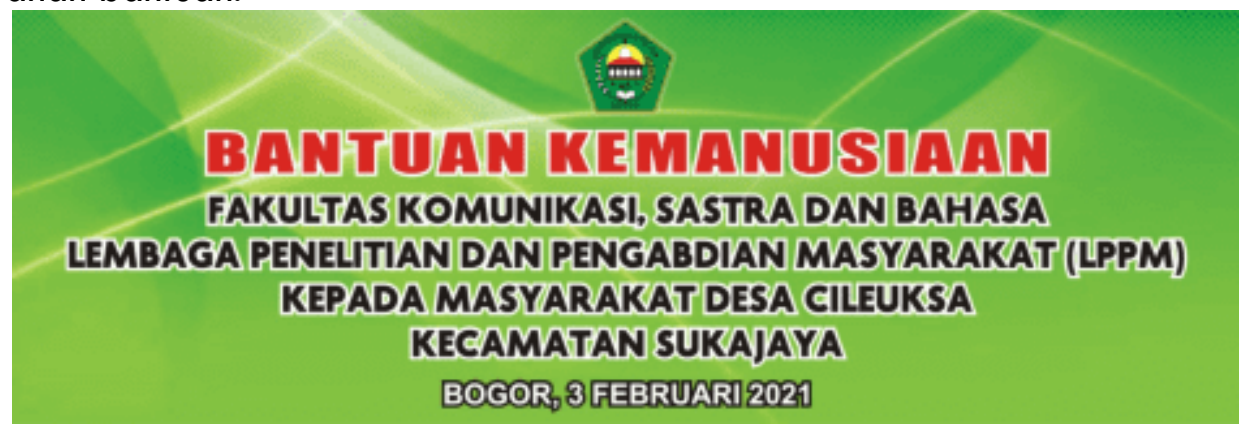

Gambar 9. Poster Kegiatan Desa Cileuksa

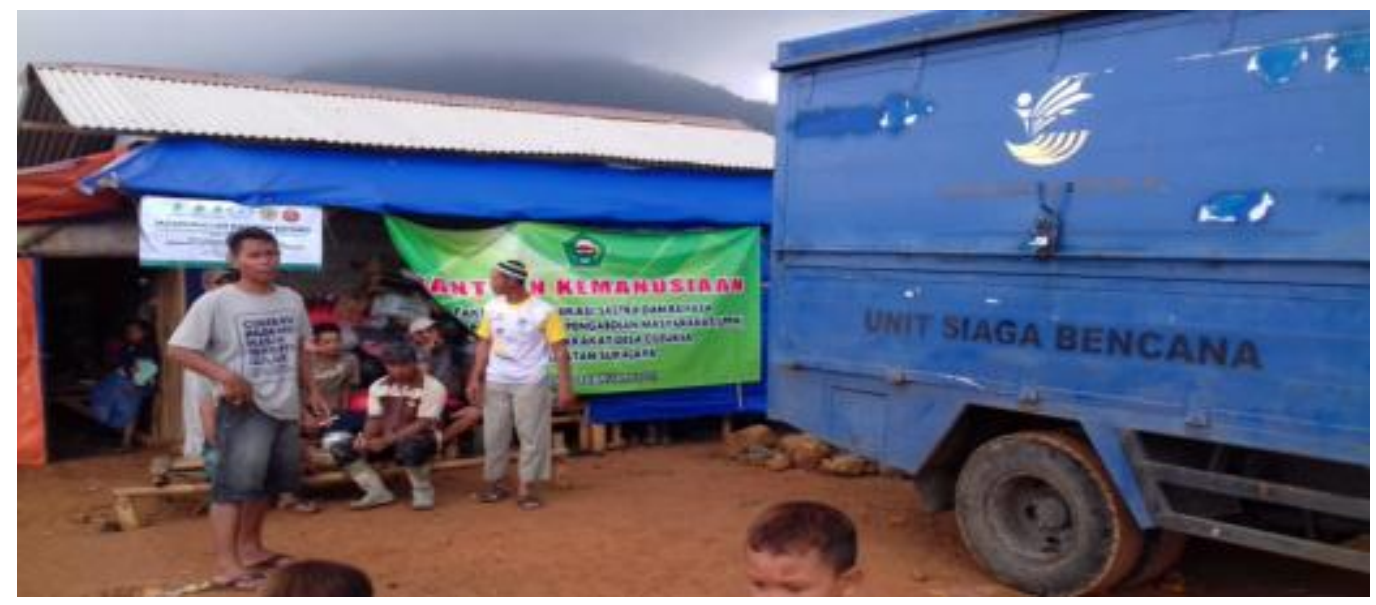

Gambar 10. Tahap Penyerahan Bantuan 


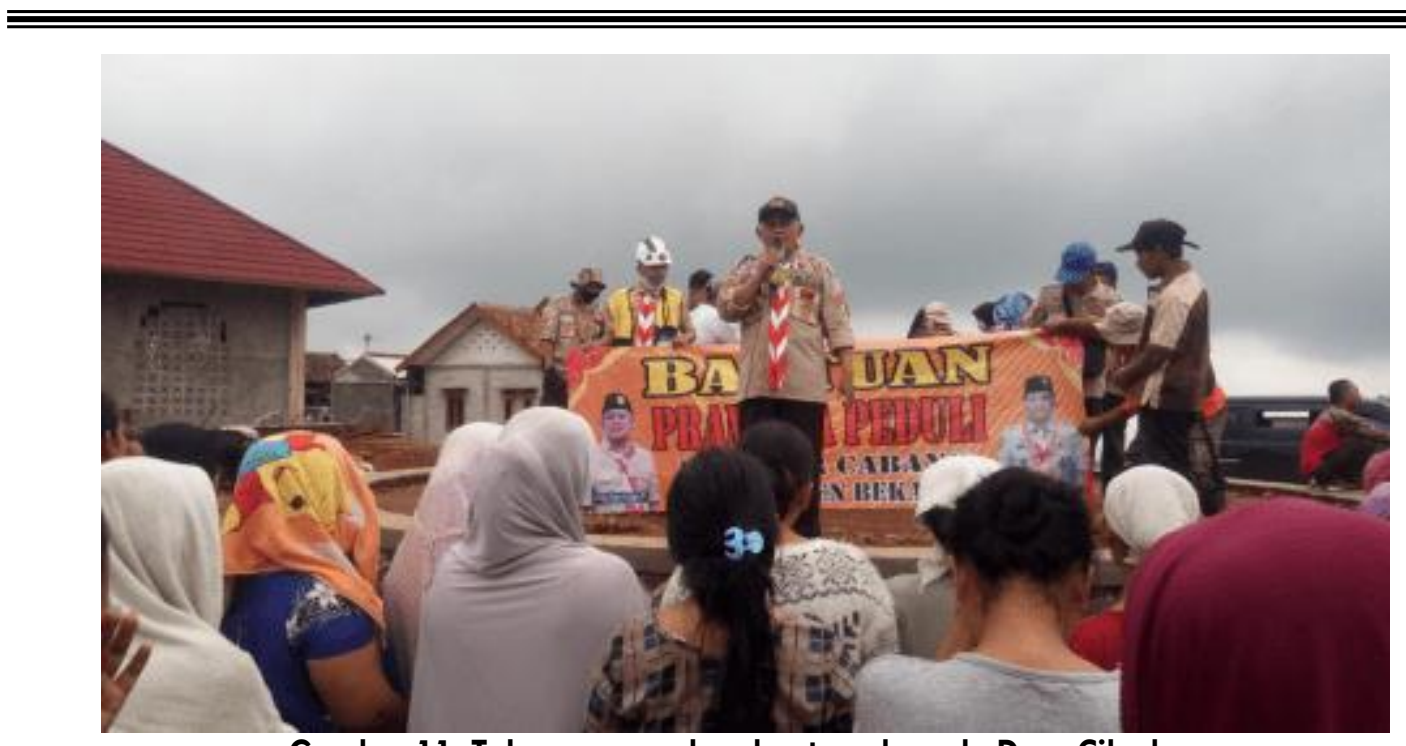

Gambar 11. Tahap penyerahan bantuan kepada Desa Cileuksa

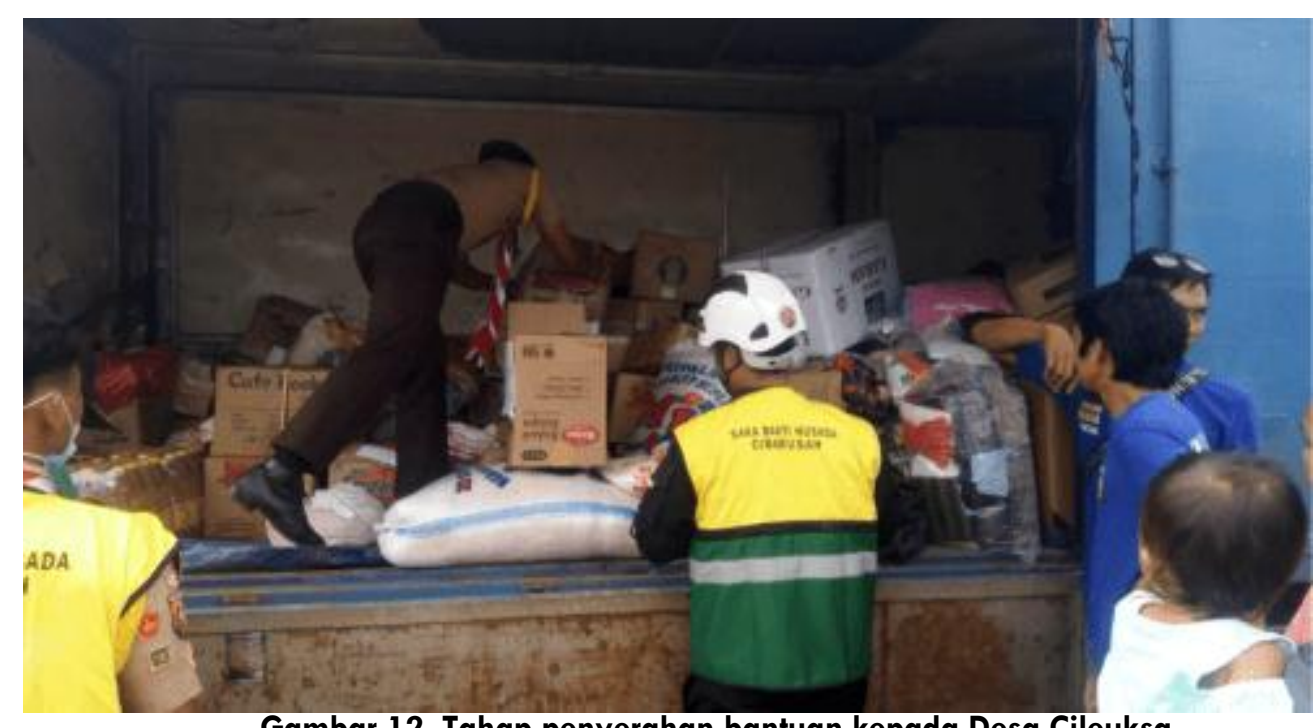

Gambar 12. Tahap penyerahan bantuan kepada Desa Cileuksa

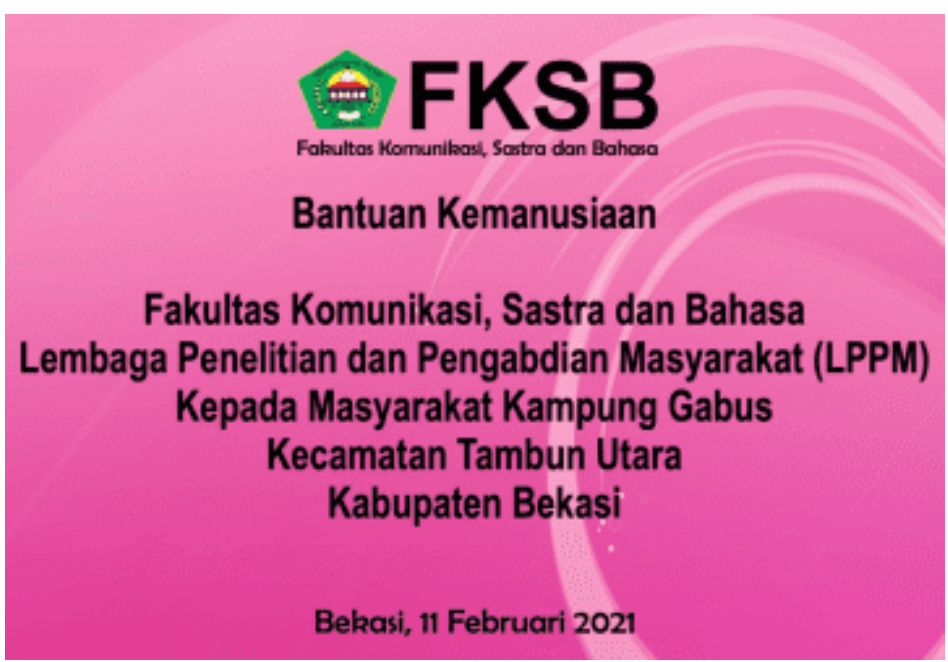

Gambar 13. Poster kegiatan baksos Kabupaten Bekasi 


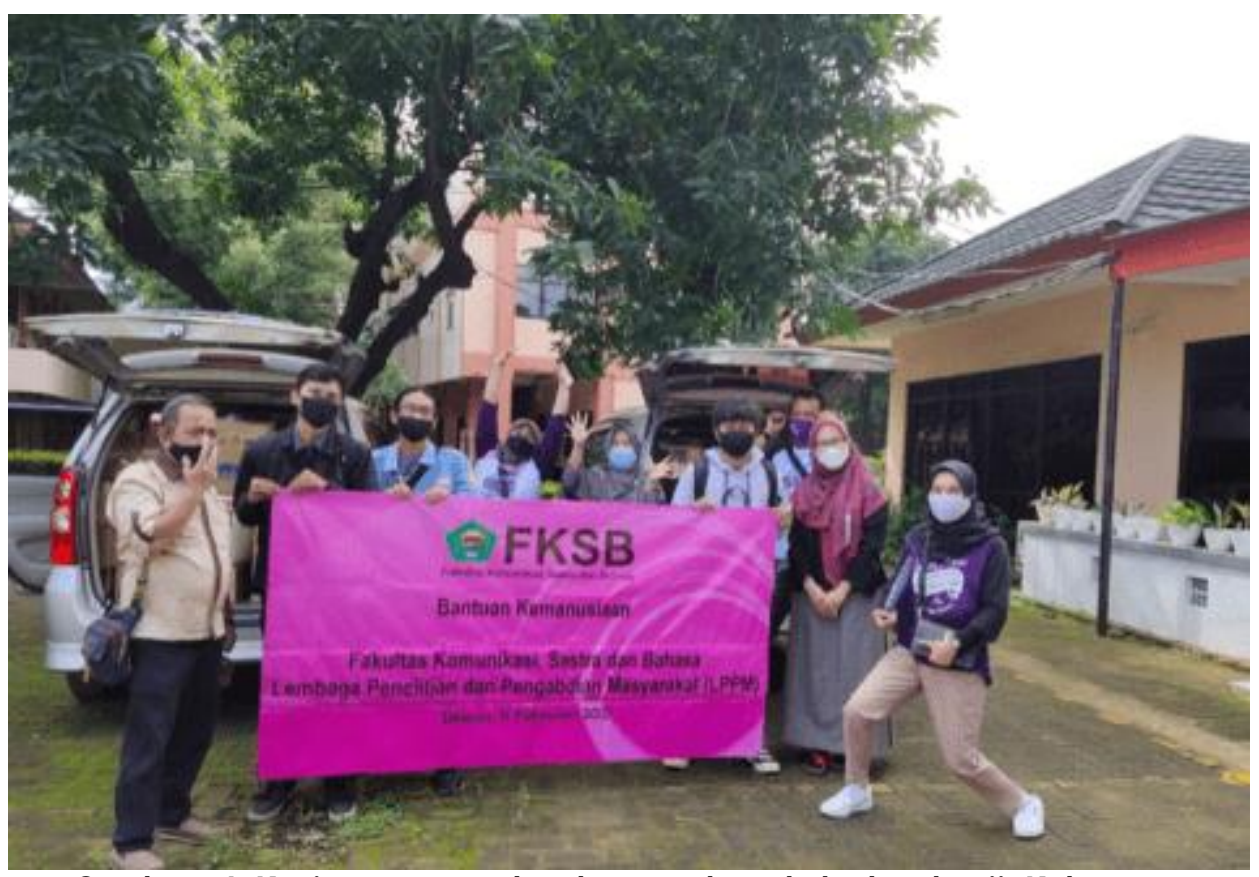

Gambar 14. Kegiatan penyerahan bantuan kepada korban banjir Kabupaten Bekasi

\section{HASIL ATAU PEMBAHASAN}

Kegiatan bakti sosial berupa penggalangan dana dan penyaluran bantuan sandang dan pangan dilakukan oleh sivitas FKSB Universitas Islam 45 Bekasi yang bekerjasama dengan Kwarcab Pramuka Kota Bekasi kepada para penyintas bencana banjir dan longsor Desa Cileuksa. Lokasi pemberian bantuan dipilih karena para penyintas bencana banjir dan longsor Desa Cileuksa masih merasakan efek dari bencana yang menimpa mereka.

Kegiatan dilakukan dalam tiga tahap yaitu penggalangan dana yang dilakukan secara daring mengingat keadaan pandemi Covid-19, penyortiran bantuan dan penyerahan bantuan kepada Kwarcab Pramuka Kota Bekasi. Pendistribusian bantuan dipercayakan kepada Kwarcab Pramuka Kabupaten Bekasi karena dianggap berpengalaman dalam mendistribusikan bantuan kepada korban-korban bencana. Sedangkan penyerahan bantuan untuk korban-korban banjir di Kabupaten Bekasi dilakukan oleh anggota tim pengabdian masyarakat FKSB Universitas Islam 45 Bekasi karena lokasinya yang dekat dari FKSB Universitas Islam 45 Bekasi.

Sebagai bentuk monitoring terhadap penyaluran bantuan, kami bekerjasama dengan Kwarcab Pramuka Kabupaten Bekasi untuk penyerahan laporan berupa dokumentasi dan surat tanda penyerahan bantuan untuk Desa Cileuksa. Sedangkan bentuk monitoring untuk para penyintas banjir di Kabupaten Bekasi dilakukan oleh tim dari FKSB Universitas Islam 45 Bekasi berupa penyerahan bantuan secara langsung. Sebagai bentuk dari pertanggungiawaban terhadap semua pihak yang terlibat, tim dari FKSB Universitas Islam 45 Bekasi mengumpulkan semua dokumentasi penyerahan bantuan dan mengubahnya ke bentuk video untuk diunggah di situs YouTube dengan link berikut ini https://youtu.be/_w9sB9_6CK8. Hasil evaluasi dari kegiatan ini berupa respon masyarakat atas penyerahan bantuan sosial. Kebanyakan penyintas memberikan respon positif terhadap bantuan yang diberikan. Berikut adalah hasil survey kepuasan yang diberikan kepada beberapa penerima bantuan: 
Tabel 1. Hasil Survey Kepuasan Penerima Bantuan Program Pengabdian Masyarakat FKSB

\begin{tabular}{|c|c|c|c|c|c|}
\hline No & Unsur Penilaian & $\begin{array}{c}\text { Indikator } \\
\text { Penilaian }\end{array}$ & $\begin{array}{c}\text { Indeks } \\
\text { Kepuasan }\end{array}$ & $\begin{array}{c}\text { Persentase } \\
(\mathbf{N = 5 0})\end{array}$ & Keterangan \\
\hline 1 & Prosedur Pembagian & Tepat Waktu & 3,41 & $80 \%$ & Sangat Baik \\
\cline { 3 - 6 } & & Merata/Adil & 3,31 & $75 \%$ & Baik \\
\hline 2 & $\begin{array}{c}\text { Perilaku Pembagian } \\
\text { Bantuan }\end{array}$ & Sopan & 3,51 & $80 \%$ & Sangat Baik \\
\cline { 3 - 6 } & Ramah & 3,61 & $85 \%$ & Sangat Baik \\
\hline 3 & $\begin{array}{c}\text { Harapan Untuk Jenis } \\
\text { Program Selanjutnya }\end{array}$ & $\begin{array}{c}\text { Pendampingan } \\
\text { Usaha }\end{array}$ & - & $55 \%$ & - \\
\hline & & Pelatihan & - & $45 \%$ & - \\
\hline
\end{tabular}

Terlepas dari usaha untuk meminimalisirnya, program ini tidak lepas dari kekurangan. Karena program ini bersifat bantuan jangka pendek, sulit untuk mengukur tingkat dampak berkelanjutan. Oleh karena itu program ini hanya bersifat sebagai titik tolak untuk program-program pengabdian masyarakat selanjutnya yang bersifat ke arah pemberdayaan masyarakat seperti pemberian keterampilan atav ilmu pengetahuan yang dapat digunakan para penyintas untuk mencari penghasilan.

\section{PENUTUP.}

Banjir merupakan bencana alam yang paling sering terjadi di Indonesia. Oleh karena itu, perhatian terhadap penyintas bencana banjir perlu dilakukan. FKSB Universitas Islam 45 Bekasi, sebagai bentuk dari rasa syukur dan mengaplikasian dari motto Universitas Islam 45 Bekasi yaitu mewujudkan insan yang khairu ummah, membuat kegiatan penyerahan bantuan sosial kepada penyintas bencana banjir dan longsor di Desa Cileuksa dan Kabupaten Bekasi.

Berdasarkan penguraian kegiatan Pengabdian Masyarakat di atas kami berharap di masa mendatang dapat memberikan bantuan yang berkelanjutan kepada pihak-pihak yang membutuhkan. Selain itu, kami berharap bisa memberikan contoh yang nyata mengenai komitmen kami dalam menciptakan insan yang berguna bagi masyarakat sekitar. Walaupun begitu, kegiatan ini tidak tanpa kekurangan. Karena kegiatan ini bersifat bantuan jangka pendek, evaluasi kegiatan sulit dilakukan. Di kemudian hari, perlu ada kegiatan kelanjutan yang berhubungan dengan pemberdayaan para penyintas bencana banjir dan longsor di kedua tempat.

\section{E. UCAPAN TERIMAKASIH}

Ucapan terimakasih kami persembahkan kepada Allah SWT atas berkah dan nikmat yang telah diberikan. Kami juga mengucapkan terimakasih kepada LPPM Universitas Islam 45 Bekasi yang telah memfasilitasi kegiatan kami ini. Tidak lupa kami berterimakasih kepada Kwarcab Pramuka Kabupaten Bekasi atas bantuannya dalam distribusi bantuan kepada Desa Cileuksa. Selain itu kami ingin berterimakasih kepada semua donatur yang telah memberikan bantuan untuk para penyintas bencana banjir.

\section{F. DAFTAR PUSTAKA.}

Abdullah M Surjaya. (2021). Banjir Kabupaten Bekasi Rendam 12 Kecamatan. Metro.Sindonews.Com. https://metro.sindonews.com/read/327464/170/banjirkabupaten-bekasi-rendam-12-kecamatan- 1612684975

Besty Charmin Simatupang. (2018). Indonesia Rawan Banjir, Perlu Kewaspadaan Tinggi untuk Tanggap Bencana. Rri.Co.Id. https://rri.co.id/editorial/1316/indonesiarawan-banjir-perlu-kewaspadaan-tinggi-untuk-tanggap-bencana

Binti Mufarida. (2021). Indonesia Rawan Bencana, Luhut: Kita Harus Siap Menghadapinya. 
Sindonews. https://nasional.sindonews.com/read/353852/15/indonesia-rawanbencana-luhut-kita-harus-siap-menghadapinya-1614830627

CNN. (2020). Doni Monardo: RI Masuk 35 Negara Rawan Bencana di Dunia. CNN Indonesia. https://www.cnnindonesia.com/nasional/20201215141037-20582358 /doni-monardo-ri-masuk-35-negara-rawan-bencana-di-dunia

Emir Yanwardhana. (2021). Warning! Hampir 40\% Bencana Alam di RI Akibat Banjir. CNBC Indonesia. https://www.cnbcindonesia.com/news/20210218125052-4224289/warning-hampir-40-bencana-alam-di-ri-akibat-banjir

Faradilla, M. (2018). Peran Tenaga Kefarmasian dalam Penanggulangan Bencana (Role of Pharmacist in Disaster Management). Pharmaceutical Sciences and Research, 5(1), 14-18.

Friski Riana. (2021). Selain Dana Rp 3,5 M, BNPB Kucurkan Bantuan Rumah Rusak Korban Banjir Kalsel. Tempo.Co. https://nasional.tempo.co/read/1424213/selain-dana-rp35-m-bnpb-kucurkan-bantuan-rumah-rusak-korban-banjir-kalsel/full\&view=ok

Hapsoro, A. W., \& Buchori, I. (2015). Kajian kerentanan sosial dan ekonomi terhadap bencana banjir. Jurnal Teknik PWK, 4(4), 542-553.

Indonesia Dermawan. (2020). Bangun Hunian Nyaman untuk Penyintas Banjir di Bogor. https://indonesiadermawan.id/campaign/1892/bangun-hunian-nyaman-untukpenyintas-banjir-di-bogor

Khadafi, M. (2021). Indonesia Rawan Gempa dan Banjir, Begini Tips Antisipasi Bencana. Bisnis.Com. https://kabar24.bisnis.com/read/20210119/15/1344683/indonesiarawan-gempa-dan-banjir-begini-tips-antisipasi-bencana

Nur, A., \& Dampung, V. M. (2020). Penanggulangan Kesehatan Dalam Kondisi Pasca Bencana Dusun Ujung Indah, Desa Cilellang, Kecamatan Mallusettasi, Kabupaten Barru. INDRA: Jurnal Pengabdian Kepada Masyarakat, 1(1), 11-14. https://doi.org/10.29303/indra.v1il.1

Reza Mardhani. (2020). Mengalirkan Air Bersih di Kawasan Pengungsian Blok Cipendawa. ACT News. https://news.act.id/berita/mengalirkan-air-bersih-di-kawasanpengungsian-blok-cipendawa

Umar Nurlailah. (2013). Pengetahuan Dan Kesiapsiagaan Masyarakat Menghadapi Bencana Banjir Di Bolapapu Kecamatan Kulawi Sigi Sulawesi Tengah. Jurnal Keperawatan Soedirman, 8(3), 184-192.

UNS, H. (2020). Pentingnya Pengabdian Masyarakat sebagai Bakti kepada Negeri. Universitas Sebelas Maret. https://uns.ac.id/id/uns-update/pentingnyapengabdian-masyarakat-sebagai-bakti-kepada-negeri.html

Yuni Astutik. (2021). BRINS Salurkan Bantuan untuk Korban Banjir \& Gempa. CNBC

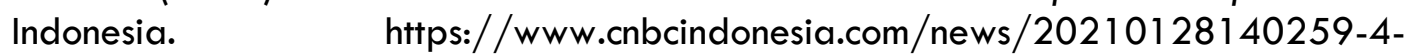
219420/brins-salurkan-bantuan-untuk-korban-banjir-gempa 